\title{
Clinical Pharmacology of Rocuronium in Infants and Children
}

\author{
Gian Maria Pacifici
}

Associate Professor of Pharmacology via Sant' Andrea 32, 56127 Pisa, Italy

Corresponding Author: Gian Maria Pacifici, Associate Professor of Pharmacology via Sant' Andrea 32, 56127 Pisa.

Received date: December 16, 2021; Accepted date: December 25, 2021; Published date: January 05, 2022

Citation: Gian Maria Pacifici, (2022) Clinical Pharmacology of Rocuronium in Infants and Children. J, Clinical Case Reports and Studies 3(2); DOI: $10.31579 / 2690-8808 / 102$

Copyright: (C) 2022 Gian Maria Pacifici, This is an open access article distributed under the Creative Commons Attribution License, which permits unrestricted use, distribution, and reproduction in any medium, provided the original work is properly cited.

\begin{abstract}
The main clinical use of the neuromuscular blocking agents is an adjuvant in surgical anaesthesia to obtain relaxation of skeletal muscle, particularly of the abdominal wall, to facilitate surgical manipulations. Rocuronium can be used instead of suxamethonium to provide rapid muscle paralysis during tracheal intubation but the recovery is much slower. Rocuronium is administered intravenously to infants and children. In infants, rocuronium is administered at a dose of $450 \mu \mathrm{g} / \mathrm{kg}$ for providing muscle relaxation for laryngeal intubation. To provide sustained paralysis, rocuronium is given at a dose of $600 \mu \mathrm{g} / \mathrm{kg}$. In children, the neuromuscular blockade is obtained with $600 \mu \mathrm{g} / \mathrm{kg}$ followed by an intravenous infusion of $150 \mu \mathrm{g} / \mathrm{kg}$ per hour. For assisted ventilation in intensive care, rocuronium is administered at a dose of $600 \mu \mathrm{g} / \mathrm{kg}$ followed by an intravenous infusion of 300 to $600 \mu \mathrm{g} / \mathrm{kg}$ per hour. The effects of rocuronium have been extensively studied in infants and children. Rocuronium is converted into 17-desacetyl rocuronium. The pharmacokinetics of rocuronium have been studied in infants and children and the mean residence time is 55.6 and $25.6 \mathrm{~min}(\mathrm{P}$-value $<0.01)$ in infant and children, respectively. Rocuronium interacts with drugs, the treatment of infants and children with rocuronium has been studied, and rocuronium poorly crosses the human placenta. The aim of this study is to review the published data on rocuronium dosing, pharmacokinetics, and treatment in infants and children, and rocuronium metabolism and transfer across the human placenta.
\end{abstract}

Key Words: rocuronium; dosing; effects; metabolism; pharmacokinetics; treatment; placental-transfer; infants; and children

\section{Introduction}

Mechanism of action of neuromuscular blocking agents

Competitive antagonists bind the nicotine acetylcholine receptor in skeletal muscle and thereby competitively block the binding of acetylcholine. The depolarizing agents, such as succinylcholine, depolarize the membrane by opening channels in the same manner as acetylcholine. However, they persist longer at the neuromuscular junction primarily because of their resistance to acetylcholine. The depolarisation is thus longer lasting, resulting in a brief period of repetitive excitation that may elicit transient and repetitive muscle excitation (fasciculations), followed by blocking of neuromuscular transmission and flaccid paralysis (called phase I block). The block arises because, after an initial opening, perjunctional $\mathrm{Na}^{+}$channels close and will not reopen until the end plate is repolarized. At this point, neural release of acetylcholine results in the binding of acetylcholine to receptors on an already-depolarized end plate. These closed perjunctional channels keep the depolarization signal from effecting downstream channels and effectively shield the rest of the muscle from activity at the motor end plate. This sequence is influenced by such factors as the anaesthetic agent used concurrently, the type of muscle, and the rate of drug administration. Under clinical condition, with increasing concentrations of succinylcholine and over time, the block may convert slowly from a depolarizing phase I block to a non-depolarizing phase II block. While the response to peripheral stimulation during phase II block by administration of anti-acetylcholine agents (e.g., neostigmine) is difficult to predict and should be undertaken cautiously. Many drugs and toxins block neuromuscular transmission by other mechanisms, such as interference with the synthesis or realised acetylcholine, but most of these agents are not employed clinically for neuromuscular blockade. One exception is the group of botulinum toxins, which are administered locally into muscles of the orbit in the management of ocular blepharospasm and strabismus and have been used to control other muscle spasm and to facilitate facial muscle relaxation. This toxin also has been injected into the lower oesophageal sphincter to treat achalasia [1].

Muscular relaxation of neuromuscular blocking agents 
The main clinical use of the neuromuscular blocking agents is an adjuvant in surgical anaesthesia to obtain relaxation of skeletal muscle, particularly of the abdominal wall, to facilitate operative manipulations. With muscle relaxation no longer dependent on the depth of general anaesthesia, a much lighter level of anaesthesia suffices. Thus, the risk of respiratory and cardiovascular depression is minimized, and post-anaesthetic recovery is shortened. Neuromuscular blocking agents of short duration often are used to facilitate endotracheal intubation and have been used to facilitate laryngoscopy, bronchoscopy, and esophagoscopy in combination with a general anaesthetic agent. Neuromuscular blocking agents are administered parenterally, nearly always intravenously. These agents may be administered by continuous infusion in the intensive care setting for improving chest wall compliance and eliminating ventilator dyssynchrony [1].

\section{Clinical use of rocuronium}

Rocuronium can be used instead of suxamethonium to provide rapid muscle paralysis during tracheal intubation, but the recovery is much slower. Vecuronium is a similarly long-acting paralytic agent but takes longer to work. Atracurium and mivacurium are useful (but slower acting) alternatives when short-term paralysis is all that is required, but are more likely to trigger histamine release [2]. Rocuronium is used for muscle relaxation/paralysis in patients requiring endotracheal intubation. Rocuronium is an aminosteroid non-depolarizing neuromuscular blocking agent that is an analogue of vecuronium with 10 to $15 \%$ of its potency. It has a rapid to intermediate onset depending on the dose and intermediate duration. It acts by competing for cholinergic receptors at the motor end-plate. This action is antagonized by acetylcholinesterase inhibitors, such as neostigmine and edrophonium. The plasma levels of rocuronium follow a three compartment open model following intravenous administration. The rapid distribution half-life is 1 to $2 \mathrm{~min}$ and the sower distribution half-life is 14 to $18 \mathrm{~min}$. Onset of clinical effect usually occurs within $2 \mathrm{~min}$ and the duration ranges from $20 \mathrm{~min}$ to 2 hours. Larger doses (900 to $1,200 \mu \mathrm{g} / \mathrm{kg}$ ) lead to more rapid onset and larger duration of clinical effect. It can have differential effects on various muscle groups (e.g., laryngeal versus adductor pollicis versus diaphragm). The onset of laryngeal adductor paralysis is significantly slower with rocuronium compared to succinylcholine. Despite this difference, rocuronium has the fastest onset of any currently available non-depolarizing muscle relaxant. The average half-life in newborns is 1.1 hours. Rocuronium is approximately $30 \%$ protein bound, and is primary excreted by the liver [3].

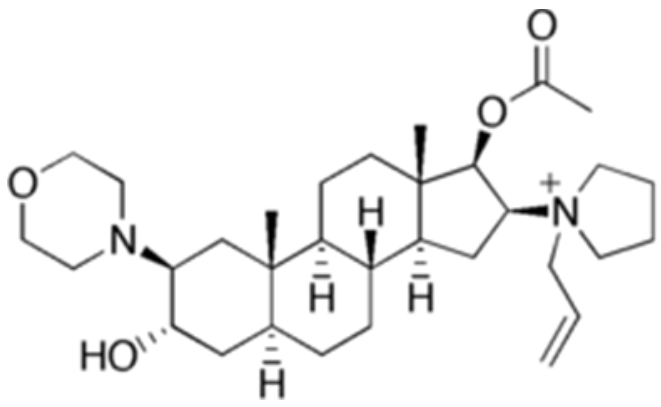

Rocuronium molecular structure (molecular weight $=529.7742$ grams $/$ mole $)$

\section{Literature search}

The literature search was performed electronically using PubMed database as search engine and the following key words were used: "rocuronium dosing infants, children", "rocuronium effects infants, children, "rocuronium adverse-effects infants, children", "rocuronium metabolism", "rocuronium pharmacokinetics infants, children", "rocuronium drug interactions", "rocuronium treatment infants, children", and "rocuronium placental transfer". In addition, the books: The Pharmacological Basis of Therapeutics [1], Neonatal Formulary [2], NEOFAX $^{\circledR}$ by Young and Mangum [3], and The British National Formulary for Children [4] have been consulted.

\section{Results}

\section{Administration schedules or rocuronium to infants and children}

Intravenous administration to infants [2]

Brief use to effect intubation: $450 \mu \mathrm{g} / \mathrm{kg}$ of rocuronium provides the muscle relaxation needed to effect easy laryngeal intubation within a min in infants $<1$ year old, but recovery may take 1 hour. A larger dose does not speed the onset of paralysis and may double recovery time in a young infants.

Use to provide sustained paralysis: Start giving $600 \mu \mathrm{g} / \mathrm{kg}$ of rocuronium by intravenous injection. Most infants continue to comply with the imposed ventilator rate as they wake from this first paralysing dose (especially if a moderately fast rate and a relatively short inspiratory time is used) but a few require prolonged paralysis. The standard repeat dose is a quarter to half the initial dose given intravenously every 2 to 4 hours as necessary but some older infants seem to require a higher maintenance dose. Paralysed infants should always be sedated. An infusion of 300 to $600 \mu \mathrm{g} / \mathrm{kg}$ per hour adjusted according to the response is an alternative to intermittent dosing.

Intravenous administration for neuromuscular blockade (intermediate duration) during surgery [4]

Children. Give initially $600 \mu \mathrm{g} / \mathrm{kg}$, and then (by intravenous injection) $150 \mu \mathrm{g} / \mathrm{kg}$, repeat the dose if necessary, alternatively (by intravenous infusion) 300 to $600 \mu \mathrm{g} / \mathrm{kg}$ per hour, adjust the dose according to the response.

Intravenous administration for assisted ventilation in intensive care [4]

Children. Give initially $600 \mu \mathrm{g} / \mathrm{kg}$, initial dose is optimal, and then (by intravenous infusion) give 300 to $600 \mu \mathrm{g} / \mathrm{kg}$ per hour for the first hour, and then (by intravenous infusion) adjust the dose according to the response.

\section{Effects of rocuronium in infants and children}

Rocuronium facilitates successful intubation and provided clinical paralysis quickly in term and preterm infants [5]. Six-hundred $\mu \mathrm{g} / \mathrm{kg}$ of rocuronium has a rapid onset of effect in infants and prolonged duration of action in infants compared to children [6]. Neuromuscular blockade induced by rocuronium can be effectively reversed with sugammadex $2 \mathrm{mg} / \mathrm{kg}$ in children aged 1 to 12 years [7]. A dose of $450 \mu \mathrm{g} / \mathrm{kg}$ 
rocuronium results in rapid relaxation and safe ventilation in paediatric patents undergoing rigid bronchoscopy [8]. Rocuronium at intubating doses of 450,600 or $1,000 \mu \mathrm{g} / \mathrm{kg}$ is effective in producing rapid-onset neuromuscular blockade with an intermediate duration of action in paediatric patients during sevoflurane induction/isoflurane maintenance anaesthesia [9]. Intramuscular rocuronium does not consistently provide satisfactory tracheal intubating conditions in infants and children and is not an adequate alternative to intramuscular succinylcholine when rapid intubation is necessary [10]. Deltoid injections of rocuronium at a dose of $1,000 \mu \mathrm{g} / \mathrm{kg}$ in infants and $1,800 \mu \mathrm{g} / \mathrm{kg}$ in children rapidly permit tracheal intubation in infants and children, despite a light plane of anaesthesia [11]. The emergency recovery following an average $94.5 \pm 4.8 \%$ neuromuscular blockade established by rocuronium is roughly similar in infants and children. Thus, one ED95 dose of rocuronium, unlike vecuronium, acts as an intermediate-acting agent in infants and children [12]. Rocuronium has a rapid onset and intermediate duration of action in children aged 4 to 12 years and appears to devoid significant adverse-effects [13]. Rocuronium reduces the frequency of oculocardiac reflex mainly by reducing the incidence of supraventricular and ventricular premature beats [14]. Rocuronium given at a dose of $300 \mu \mathrm{g} / \mathrm{kg}$ during halothane anaesthesia causes neuromuscular depression and has a longer duration of action in infants than in children older than 2 years [15].

\section{Adverse-effects caused by rocuronium in infants and children [4]}

\section{Uncommon adverse-effects}

Procedural complications and tachycardia.

\section{Rare or very rare adverse-effects}

Angioedema, circulatory collapse, face oedema, malignant hyperthermia, paralysis, and shock.

\section{Metabolism of rocuronium}

In literature there is only one study on rocuronium metabolism and it has been reported by Proost et al. [16]. In samples of human urine, bile, and faeces only small amounts of rocuronium metabolite 17-desacetylrocuronium have been found.

\section{$\mathrm{Br}^{-}$}<smiles>C=CC[N+]1(C2C[C@@H]3C4CC[C@H]5C[C@H](O)C(N6CCOCC6)C[C@]5(C)[C@H]4CC[C@]3(C)[C@H]2O)CCCC1</smiles>

\section{7-Desacetyl Rocuronium bromide molecular structure $($ molecular weight $=567.6$ grams $/ \mathrm{mole})$}

\section{Pharmacokinetics of rocuronium in infants and children}

Wierda et al. [17] studied the pharmacokinetics of rocuronium in 5 infants aged 0.1 to 0.8 years and in 5 children aged 2.3 to 8 years. Rocuronium was intravenously infused at a dose of $600 \mu \mathrm{g} / \mathrm{kg}$ per min to infants and at a dose of $900 \mu \mathrm{g} / \mathrm{kg}$ per min to children. Table 1 provides the surgical procedures and subject's demographic characteristics and table 2 summarizes the pharmacokinetics of rocuronium.

\begin{tabular}{|l|l|l|}
\hline Value & Infants & Children \\
\hline Surgical procedure $(\mathrm{N})$ & 2 & --- \\
\hline Tracheal resection & 1 & --- \\
\hline Aortic valvulotomy & 1 & --- \\
\hline Aortic coarctation resection & 2 & 4 \\
\hline Atrial septum closure & --- & 1 \\
\hline Ventricular septum closure & --- & $5.4(2.3-8.0)$ \\
\hline Age (years) & $0.5(0.1-0.8)$ & $19.1 \pm 4.9(13.8-27.0)$ \\
\hline Body-weight $(\mathrm{kg})$ & $6.0 \pm 2.1(4.7-9.6)$ &
\end{tabular}

Table 1: Subject data and surgical procedures. Figures are the subject number or mean \pm SD, and (range) by Wierda et al. [17].

\begin{tabular}{|l|l|l|l|}
\hline Variable & Infants & Children & $*$ P-value \\
\hline $\mathrm{Cl}_{\mathrm{pl}}(\mathrm{ml} / \mathrm{min} / \mathrm{kg})$ & $4.19 \pm 0.43(3.88-4.93)$ & $6.66 \pm 1.05(5.65-8.09)$ & $<0.01$ \\
\hline $\mathrm{Cl}_{12}(\mathrm{ml} / \mathrm{min} / \mathrm{kg})$ & $15.1 \pm 4.0(8.8-19.2)$ & $10.4 \pm 2.2(7.5-13.2)$ & $\mathrm{NS}$ \\
\hline $\mathrm{Cl}_{13}(\mathrm{~m} / \mathrm{min} / \mathrm{kg})$ & $3.24 \pm 3.55(1.31-9.57)$ & $1.69 \pm 0.63(0.64-2.16)$ & $\mathrm{NS}$ \\
\hline $\mathrm{V}_{1}(\mathrm{ml} / \mathrm{kg})$ & $35.4 \pm 5.4(28.0-43.6)$ & $34.7 \pm 12.8(16.1-44.8)$ & $\mathrm{NS}$ \\
\hline $\mathrm{V}_{2}(\mathrm{ml} / \mathrm{kg})$ & $87.0 \pm 37.0(49.0-142)$ & $44.0 \pm 16.0(26.0-62.0)$ & $<0.05$ \\
\hline $\mathrm{V}_{3}(\mathrm{ml} / \mathrm{kg})$ & $108 \pm 16(89.0-133)$ & $86.0 \pm 34.0(49.0-139)$ & $\mathrm{NS}$ \\
\hline $\mathrm{V}^{\mathrm{ss}}(\mathrm{ml} / \mathrm{kg})$ & $231 \pm 32.0(202-283)$ & $165 \pm 44.0(120-214)$ & $<0.05$ \\
\hline
\end{tabular}




\begin{tabular}{|l|l|l|l|}
\hline MRT $(\mathrm{min})$ & $55.6 \pm 9.9(41.0-66.9)$ & $25.6 \pm 8.9(14.8-37.9)$ & $<0.01$ \\
\hline $\mathrm{K}_{\mathrm{eo}}\left(\mathrm{min}^{-1}\right)$ & $0.25 \pm 0.08(0.17-0.34)$ & $0.32 \pm 0.06(0.24-0.37)$ & $\mathrm{NS}$ \\
\hline $\mathrm{EC} 50(\mathrm{mg} / \mathrm{L})$ & $1.19 \pm 0.38(0.79-1.62)$ & $1.65 \pm 0.38(1.20-2.02)$ & $<0.05$ \\
\hline$\gamma$ & $5.74 \pm 1.28(4.78-7.97)$ & $3.91 \pm 0.51(3.12-4.56)$ & $<0.01$ \\
\hline $\mathrm{ED}_{50}(\mathrm{mg} / \mathrm{kg})$ & $0.261 \pm 0.066(0.190-0.300)$ & $0.335 \pm 0.077(0.255-0.451)$ & $\mathrm{NS}$ \\
\hline
\end{tabular}

Table 2: Pharmacokinetic parameters of rocuronium which are obtained in 5 infants and in 5 children. Figures are the mean \pm SD and (range), by Wierda et al. [17].

$\mathrm{Cl}_{\mathrm{pl}}=$ plasma clearance. $\mathrm{Cl}_{12}$ and $\mathrm{Cl}_{13}=$ distribution clearance to the second and third compartment, respectively. $\mathrm{V}_{1}, \mathrm{~V}_{2}$, and $\mathrm{V}_{3}=$ volume of the central, second and third compartments, respectively. $\mathrm{V}^{\mathrm{ss}}=$ distribution volume at steady-state. MRT = mean residence time after an intravenous bolus dose. $\mathrm{K}_{\mathrm{eo}}=$ rate constant of equilibration between central and peripheral compartments. $\mathrm{EC}_{50}=$ the concentration in the effect compartment at 50\% neuromuscular block. $\gamma=$ slope of the concentration-effect relationship in the effect compartment. $\mathrm{ED}_{50}=$ calculated bolus dose resulting in $90 \%$ block. NS $=$ not significant. *Mann-Whitney U test.

This table shows that the plasma clearance is greater in children than in infants, the volume of the second compartment is lower in children, the distribution volume at the steady state and the mean residence time are lower in children, and the concentration in the peripheral compartment at $50 \%$ neuromuscular block is greater in children, the slope of the concentration-effect relationship in the effect compartment is lower in children.

\section{Interaction of rocuronium with drugs}

The co-administration of rocuronium with cisatracurium results in a synergic effect [18]. Rocuronium inhibits the formation-rate of temazepam and desmethyldiazepam by $20 \%$ and $15 \%$, respectively, in human liver microsomes [19]. Magnesium potentiates the neuromuscular effect of rocuronium and shifts the concentration-response curve to the left [20]. The calculated doses producing 50\% depression $\left(\mathrm{ED}_{50}\right)$ of the twitch height for rocuronium, pancuronium, pipecuronium and vecuronium were $144.8,32.4,27.1$, and $23.7 \mu \mathrm{g} / \mathrm{kg}$, respectively. Corresponding doses producing $95 \%$ depression (ED95) of twitch height were, respectively, 322.1, 58.1, 48.7, and $39.9 \mu \mathrm{g} / \mathrm{kg}$. Based on the estimate of $\mathrm{ED}_{50}$, the relative potency is $1: 4,5: 5$, and 4:6, respectively. The interaction between rocuronium and vecuronium, pipecuronium or pancuronium is found to be additive [21]. Chronic therapy with anticonvulsant drugs reduces the duration of action of rocuronium [22]. Phenytoin acutely augments the neuromuscular block produced by rocuronium without altering its plasma concentration or its binding to plasma proteins [23].

\section{Treatment of infants and children with rocuronium}

Children born full-term or with birthweight $>2.5 \mathrm{~kg}$ in the cerebral palsy cohort requires more rocuronium than preterm and low birthweight counterparts [24]. Three-hundred $\mu \mathrm{g} / \mathrm{kg}$ of rocuronium is better than a lower dose of $150 \mu \mathrm{g} / \mathrm{kg}$ for clinically acceptable intubating conditions in paediatric ambulatory surgery during remifentanil-propofol-based anaesthesia at the doses used in the study [25]. Sub-paralyzing doses of rocuronium show a distinct effect on muscular endurance as opposed to momentary force. These findings support the hypothesis that low doses of rocuronium act mainly by reducing muscular endurance, thereby facilitating, for example, tracheal intubation [26]. A total of $300 \mu \mathrm{g} / \mathrm{kg}$ of rocuronium is sufficient for tracheal intubation for children aged 1 to 6 years under sevoflurane induction [27]. During inhalation induction with $8 \%$ sevoflurane in $60 \%$ nitrous oxide, rocuronium $290 \mu \mathrm{g} / \mathrm{kg}$ optimizes intubation conditions for surgery of short duration [28].

\section{Transfer of rocuronium across the human placenta}

In literature there is only one investigation of the transfer of rocuronium across the human placenta and it is reported by Abouleish et al. [29]. Rocuronium was injected at a dose of $600 \mu \mathrm{g} / \mathrm{kg}$ to 32 pregnant women at delivery.

\begin{tabular}{|l|l|l|l|l|}
\hline Parameter & Mean+SEM & Range & Median & Ratio of means \\
\hline $\begin{array}{l}\text { Maternal venous blood } \\
(\mathrm{ng} / \mathrm{ml})\end{array}$ & $2,412 \pm 180$ & $1,120-6,300$ & 2,200 & -- \\
\hline $\begin{array}{l}\text { Umbilical venous blood } \\
(\mathrm{ng} / \mathrm{ml})\end{array}$ & $390 \pm 27.8$ & $50-931$ & 349 & --- \\
\hline $\begin{array}{l}\text { Umbilical arterial blood } \\
(\mathrm{ng} / \mathrm{ml})\end{array}$ & $271 \pm 34.7$ & $72-495$ & 277 & -- \\
\hline $\begin{array}{l}\text { Umbilical vein to } \\
\text { maternal ratio }\end{array}$ & --- & --- & --- & 0.191 \\
\hline $\begin{array}{l}\text { Umbilical arterial to } \\
\text { maternal ratio }\end{array}$ & --- & --- & 0.620 \\
\hline
\end{tabular}

Table 3: Maternal and fetal plasma concentrations of rocuronium which are obtained in 32 maternal and fetal pairs. Figures are the mean \pm SEM, range, and median, by Abouleish et al. [29].

This table shows that rocuronium poorly crosses the human placenta and rocuronium concentration is higher in the umbilical vein blood than in the umbilical arterial blood.

\section{Discussion}

The main clinical use of the neuromuscular blocking agents is an adjuvant in surgical anaesthesia to obtain relaxation of skeletal muscle, particularly of the abdominal wall, to facilitate surgical manipulations. Neuromuscular blocking agents of short duration often are used to facilitate endotracheal intubation and have been used to facilitate 
laryngoscopy, bronchoscopy, and esophagoscopy in combination with a general anaesthetic agent [1]. Rocuronium can be used instead of suxamethonium to provide rapid muscle paralysis during tracheal intubation, but the recovery is much slower. Vecuronium is a similarly long-acting paralytic agent but takes longer time to work. Atracurium and mivacurium are useful (but slower acting) alternatives when short-term paralysis is all that is required, but are more likely to trigger histamine release [2]. Rocuronium is used for muscle relaxation/paralysis in patients requiring endotracheal intubation. Rocuronium is an aminosteroid nondepolarizing neuromuscular blocking agent that is an analogue of vecuronium with 10 to $15 \%$ of its potency. It has a rapid to intermediate onset depending on dose and intermediate duration. Rocuronium acts by competing for cholinergic receptors at the motor end-plate. Rocuronium can have differential effects on various muscle groups (e.g., laryngeal versus adductor pollicis versus diaphragm). The onset of laryngeal adductor paralysis is significantly slower with rocuronium compared to succinylcholine. Despite this difference, rocuronium has the fastest onset of any currently available non-depolarizing muscle relaxant [3]. Rocuronium is administered intravenously to infants and children. In infants, the dose to produce a brief effect for intubation is $450 \mu \mathrm{g} / \mathrm{kg}$ and the dose for providing a sustained paralysis is $600 \mu \mathrm{g} / \mathrm{kg}$ [2]. In children, the dose for neuromuscular blockade is $600 \mu \mathrm{g} / \mathrm{kg}$ followed by $150 \mu \mathrm{g} / \mathrm{kg}$ [4]. The effects caused by rocuronium have been extensively studied in infants and children [5-15]. Rocuronium is used to provides clinical paralysis to facilitates intubation in term and preterm infants [5], a dose of $600 \mu \mathrm{g} / \mathrm{kg}$ rocuronium has a more prolonged onset of effect in infants than in children [6], the neuromuscular blockade induced by rocuronium is reversed by $2 \mathrm{mg} / \mathrm{kg}$ sugammadex [7], a dose of $450 \mu \mathrm{g} / \mathrm{kg}$ results in a rapid relaxation in paediatric patients undergoing rigid bronchoscopy [8], rocuronium at a dose of 450,600 , or $1,000 \mu \mathrm{g} / \mathrm{kg}$ produces neuromuscular blockade in paediatric patients during anaesthesia [9], intramuscular rocuronium does not provide satisfactory tracheal intubation conditions in infants and children and is not alternative to succinylcholine [10], deltoid injections of rocuronium at a dose of $1,000 \mu \mathrm{g} / \mathrm{kg}$ to infants and $1,800 \mu \mathrm{g} / \mathrm{kg}$ to children permit tracheal intubation [11], the emergency recovery of neuromuscular blockade established by rocuronium is similar in infants and children [12], rocuronium produces neuromuscular blockade in children without producing adverse-effects [13], rocuronium reduces the frequency of oculocardiac reflex in children [14], and a rocuronium dose of $300 \mu \mathrm{g} / \mathrm{kg}$ causes neuromuscular depression in infants and children undergoing anaesthesia [15]. Rocuronium is converted into 17-desacetyl rocuronium and this metabolite appears in small amounts in urine, bile, and faeces [16]. The pharmacokinetics of rocuronium have been studied in infants and children and the mean residence time of rocuronium is 55.6 and 25.6 hours $(\mathrm{P}$-values $<0.01)$ in infants and children, respectively. The volumes of the central, second, and third compartments are 35.4, 87.0, and $108 \mathrm{ml} / \mathrm{kg}$ in infants and 34.7, 44.0 , and $86.0 \mathrm{ml} / \mathrm{kg}$ in children [17]. Rocuronium interacts with drugs [18-23]. The co-administration of rocuronium with cisatracurium results in a synergistic effect [18], rocuronium inhibits the formation-rate of temazepam and desmethyldiazepam [19], magnesium potentiates the neuromuscular effect of rocuronium [20], the interaction between rocuronium and vecuronium, pipecuronium or pancuronium is additive [21], anticonvulsants drugs reduce the duration of rocuronium effect [22], and phenytoin augments the neuromuscular block produced by rocuronium [23]. The treatment of infants and children with rocuronium has been studied [24-28]. Children requires more rocuronium than infants [24], a rocuronium dose of $300 \mu \mathrm{g} / \mathrm{kg}$ is better than a dose of $150 \mu \mathrm{g} / \mathrm{kg}$ for intubation paediatric patients undergoing surgery [25], low rocuronium doses act mainly by reducing muscular endurance facilitating the tracheal intubation [26], a $300 \mu \mathrm{g} / \mathrm{kg}$ rocuronium dose is sufficient for tracheal intubation in children [27], and a dose of $290 \mu \mathrm{g} / \mathrm{kg}$ rocuronium optimizes the intubation conditions for surgery [28]. Rocuronium poorly crosses the human placenta [29].
In conclusion, rocuronium is a neuromuscular agent and is used in surgical anaesthesia to reduce the relaxation of skeletal muscle, particularly of the abdominal wall, to facilitate surgical manipulations. Rocuronium is administered intravenously to infants and children. In infants, the muscular relaxation necessary for easy laryngeal intubation is obtained with $450 \mu \mathrm{g} / \mathrm{kg}$ and a dose of $600 \mu \mathrm{g} / \mathrm{kg}$ is necessary for surgery. In children, the neuromuscular blockade is obtained with $600 \mu \mathrm{g} / \mathrm{kg}$ followed by $150 \mu \mathrm{g} / \mathrm{kg}$. The effects caused by rocuronium in infants and children have been extensively studied. Rocuronium is converted into 17desacetyl rocuronium. The pharmacokinetics of rocuronium have been studied in infants and children and the mean residence time of rocuronium is 55.6 and 25.6 hours (P-value <0.01) in infants and children, respectively. Rocuronium interacts with drugs and the treatment of infants and children with rocuronium has been studied in infants and children and rocuronium is poorly transferred across the human placenta. The aim of this study is to review the clinical pharmacology of rocuronium in infants and children.

\section{Conflict of interests}

The authors declare no conflicts of financial interest in any product or service mentioned in the manuscript, including grants, equipment, medications, employments, gifts, and honoraria.

This article is a review and drugs have not been administered to men or animals.

\section{Acknowledgments}

The author thanks Dr. Patrizia Ciucci and Dr. Francesco Varricchio, of the Medical Library of the University of Pisa, for retrieving the scientific literature.

\section{References}

1. Hibbs RE, Zambon (2018) AC "Nicotine and agents acting at the neuromuscular junction and autonomic ganglia". In The Goodman \& Gilman's. The Pharmacological Basis of the Therapeutics, Brunton Hilal-dandan LL, Knollmann BC, editors. Mc Graw Hill, 13th Edition, USA, New York.; pp: 177190.

2. Neonatal Formulary. "Rocuronium": Oxford University Press. 8th Edition, Great Clarendon Street, Oxford, OX2, 6DP, UK. pp: 708-710.

3. Young TE, Mangum B. NEOFAX ${ }^{\circledR}$. "Rocuronium". Thomas Reuters Clinical Editorial Staff, 23rd Edition, Montvale, USA. 2010; pp: 236-237.

4. The British national formulary for children. (2020) "Rocuronium bromide". Macmillan, 78th Edition, Hampshire International Business Park, Hampshire, Lime Three Way, Basingstoke, Hampshire, UK. 2019-2020; pp: 842-843.

5. Feltman DM, Weiss MG, Nicoski P, Sinacore J.( 2011) Rocuronium for nonemergent intubation of term and preterm infants. J Perinatol. 31(1): 38-43.

6. Woelfel SK, Brandom BW, McGowan FX Jr, Gronert BJ, Cook DR. (1994) Neuromuscular effects of $600 \mu \mathrm{g} / \mathrm{kg}$ of rocuronium in infants during nitrous oxide-halothane anaesthesia. Ped Anest 4(3): 173-177.

7. Zhang R, Hul J, Li S, Xue B, Wang L. Bail J, et al. (2021) Effects of age on sugammadex reversal of neuromuscular blockade induced by rocuronium in Chinese children: a prospective pilot trial. al. BMC Anesthesiol. 21(10): 248-259.

8. Baş SS, Kilic Y. (2020) Clinical Effects of Different Rocuronium Doses Used in Pediatric Rigid Bronchoscopy. GKDA Derg. 26(4): 221-227. 
9. Tirotta CF, Brandom B, Siddiqui MS, Ehlers M, Betzel J, Chen J-Y, et al. (2012) Time Course of Rocuronium-Induced Neuromuscular Blockade in Pediatric Patients: A Phase III, Randomized, Dose-Response Study., J Anesthe Clinic Res. (2): 1-7.

10. Kaplan RF, Uejima T, Lobel G, Goudsouzian N, Ginsberg B, Hannallah R, et al. (1999) Intramuscular rocuronium in infants and children: a multicenter study to evaluate tracheal intubating conditions, onset, and duration of action. Anesthesiology. 91(3): 633-638.

11. Reynolds LM, Lau M, Brown R, Luks A, Fisher DM. (1996) Intramuscular rocuronium in infants and children. Doseranging and tracheal intubating conditions. Anesthesiology. 85(2): 231-239.

12. Taivainen T, Meretoja OA, Erkola O, Rautoma P, Juvakoski M. (1996) Rocuronium in infants, children and adults during balanced anaesthesia. Paediatr Anaesth. 6(4): 271-275.

13. Vuksanaj D, Skjonsby B, Dunbar BS. (1996) Neuromuscular effects of rocuronium in children during halothane anaesthesia. Paediatr Anaesth. 6(4): 277-281.

14. Karanovic N, Jukic M, Carev M, Kardum G, Dogas Z. (2004) Rocuronium attenuates oculocardiac reflex during squint surgery in children anesthetized with halothane and nitrous oxide. Acta Anaesthesiol Scand. 48(10): 1301-1315.

15. Driessen JJ, Robertson EN, Van Egmond J, Booij LH. (2000) The time-course of action and recovery of rocuronium $0.3 \mathrm{mg}$ $\mathrm{x} \mathrm{kg}(-1)$ in infants and children during halothane anaesthesia measured with acceleromyography. Paediatr Anaesth. 10(5): 493-497.

16. Proost JH, Eriksson LI, Mirakhur RK, Roest G, Wierda JM. (2000) Urinary, biliary and faecal excretion of rocuronium in humans. Br J Anaesth. 85(5): 717-723.

17. Wierda JM, Meretoja OA, Taivainen T, Proost JH. (1977) Pharmacokinetics and pharmacokinetic-dynamic modelling of rocuronium in infants and children. Br J Anaesth. 78(6): 690695.

18. Jeon S, Kwon JY, Kim H-K, Kim TK. (2016) Synergism between rocuronium and cisatracurium: comparison of the Minto and Greco interaction models. Korean J Anesthesiol. 69(4): 341-349.

19. Anzenbacherova E, Spicakova A, Jourova L, Ulrichova J, Adamus M, Bachleda P, et al. (2015) Interaction of rocuronium with human liver cytochromes P450. J Pharmacol Sci. 127(2): 190-195.

20. Fabian AI, Csernoch V, Edömér T, Tassonyi E, Fülesdi B. (2019) The effect of magnesium on the reversal of rocuroniuminduced neuromuscular block with sugammadex: an ex vivo laboratory study. BMC Anesthesiology. 19(1): 64-67.

21. Naguib M, Samarkandi AH, Bakhamees HS, Magboul MA, elBakry AK. (1995) Comparative potency of steroidal neuromuscular blocking drugs and isobolographic analysis of the interaction between rocuronium and other aminosteroids. $\mathrm{Br}$ J Anaesth. 75(1): 37-42.

22. Loan PB, Connolly FM, Mirakhur RK, Kumar N, Farling P. (1997) Neuromuscular effects of rocuronium in patients receiving beta-adrenoreceptor blocking, calcium entry blocking and anticonvulsant drugs. Br J Anaesth. 78(1): 90-91.

23. Spacek A, Nickl S, Neiger FX, Nigrovic V, Ullrich OW, Weindmayr-Goettel M, et al. 1999; (1999) Augmentation of the rocuronium-induced neuromuscular block by the acutely administered phenytoin. Anesthesiology. 90(6): 1551-1555.

24. Lee S, Robinson K, Lodge M, Theroux M, Miller F, Akins R Jr. (2021) Resistance to Neuromuscular Blockade by Rocuronium in Surgical Patients with Spastic Cerebral Palsy. $J$ Pers Med. 11(8): 765. doi: 10.3390.

25. Oztekin S, Hepaguşlar H, Kilercik H, Kar AA, Boyaci F, Elar Z. (2004) Low doses of rocuronium during remifentanilpropofol-based anesthesia in children: comparison of intubating conditions. Paediatr Anaesth. 14(8): 636-641.

26. Gelberg J, Bentzer P, Grubb D. (2019) Subparalyzing Doses of Rocuronium Reduce Muscular Endurance without Detectable Effect on Single Twitch Height in Awake Subjects. Anesthesiol Res Pract. 2897406. doi: 10.1155.

27. Hung C-T, Shih M-H, Shih C-J, Liou S-C, Kau Y-C, Chan C, et al. (2005) Intubation conditions with low dose rocuronium under sevoflurane induction for children. Chang Gung Med J. 28(3): 174-179.

28. Eikermann M, Hunkemöller I et al. (2002) Optimal rocuronium dose for intubation during inhalation induction with sevoflurane in children. Br J Anaesth. 89(2): 277-281.

29. Abouleish E, Abboud T, Lechevalier T, Zhu J, Chalian A, Alford K. (1994) Rocuronium (Org 9426) for caesarean section. Br J Anaesth. 73(3): 336-341. 


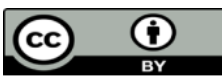

This work is licensed under Creative

Commons Attribution 4.0 License

To Submit Your Article Click Here: Submit Manuscript

DOI: $10.31579 / 2690-8808 / 099$
Ready to submit your research? Choose Auctores and benefit from:

$>$ fast, convenient online submission

$>$ rigorous peer review by experienced research in your field

$>$ rapid publication on acceptance

$>$ authors retain copyrights

$>$ unique DOI for all articles

$>$ immediate, unrestricted online access

At Auctores, research is always in progress.

Learn more auctoresonline.org/journals/journal-of-clinical-case-reportsand-studies 